\title{
BANK MERGERS, BRANCH BANKING AND BANK HOLDING COMPANIES IN PENNSYLVANIA *
}

\section{almarin Phutips $\dagger$}

Recent years have witnessed significant changes in federal policy with respect to bank mergers and bank holding companies. Of most importance is the shift from the view that banks were largely immune from action under the antitrust laws ${ }^{1}$ to the holding of the Supreme Court that the merger provisions of the Clayton Act ${ }^{2}$ as well as the monopolization and restraint of trade standards of the Sherman Act ${ }^{3}$ are applicable to banks. ${ }^{4}$ In addition, the Congress has been active, passing the Bank Holding Company Act of 1956, the Bank Merger Act of $1960^{6}$ and the Bank Merger Act of $1966 .^{7}$

These changes at the federal level have tended to obscure the significance of the so-called "dual banking system" and the importance of state law in determining the structure and competitiveness of banking markets. Branch banking in any form, save for "drive-in" tellers' windows, collections from school savings programs, etc., is prohibited in eighteen states. ${ }^{8}$ In sixteen other states, branching is permitted within certain geographically restricted areas. The remaining sixteen states allow statewide branching, but it is not unusual to find other

* This article is a revision of a report prepared for the Department of Banking, Commonwealth of Pennsylvania, for use by the Pennsylvania Banking Law Commission appointed by Governor William W. Scranton, February 1964. The views expressed are those of the author and should not be attributed to the Department of Banking or to the Banking Law Commission or to any members or employees of the Department or Commission. A complementary article, Structural and Regulatory Reform for Commercial Banking, which treats federal policy, appears in IssuEs IN Banking AND Monetary ANalysis (Hart, Pontecorvo \& Shay eds.), to be published in 1967.

$\dagger$ Professor of Economics and Law, University of Pennsylvania. B.S. 1948, M.A. 1949, University of Pennsylvania. Ph.D. 1953, Harvard University.

1 Kaysen \& Turner, Antrtrust Policy: An Economic and Legal Analysis 42-43, 291 (1959); Berle, Banking Under the Anti-Trust Laws, 49 Colum. L. REv. 589 (1949).

264 Stat. 1125 (1950), 15 U.S.C. \$ 18 (1964).

326 Stat. 209 (1890), as amended, 15 U.S.C. $\$ \S 1,2$ (1964).

4 United States v. First Nat1 Bank \& Trust Co., 376 U.S. 665 (1964) (Sherman Act); United States v. Philadelphia Nat'l Bank, 374 U.S. 321 (1963) (Clayton Act).

570 Stat. 133, as amended, 12 U.S.C. \$\$1841-48 (1964).

674 Stat. 129.

780 Stat. 7.

8 FDIC ANN. Rep. 45 (1960). 
restrictions which limit the freedom of banks to choose specific branch locations. ${ }^{9}$ In view of these state strictures there can be scant doubt that state law, not federal, has had the greater impact on the functioning of bank markets.

This article is concerned with public policies within the Commonwealth of Pennsylvania with respect to mergers among banks, de novo branch banking ${ }^{10}$ and bank holding companies. In addition, since both de novo branching and branching by merger may involve the entry of banking institutions into markets or submarkets which the branching bank had not previously served, some comments are also made concerning bank entry through new state bank chartering.

The existing legislation concerning these matters and the banking structure which has emerged during the past several years are reviewed in the section which follows. Attention is then given to the development of criteria which may be used to judge the efficiency of the structure and performance of banking markets. On the basis of the latter and on the results of a substantial and prestigious volume of recent research, ${ }^{11}$ the final section offers policy recommendations for the "commonweal."

\section{Banking Structure in Pennsyluania}

Under the current Pennsylvania code, ${ }^{12}$ the Department of Banking must approve for state-chartered banks the initial corporate chartering, ${ }^{13}$ the opening for business, ${ }^{14}$ the opening of branches, ${ }^{15}$ the reloca-

๑ For a convenient summary, see BoARd of Governors, FEDERAL Reserve System, Compilation of Federal, State, and Territorial Statutes Relating to BRANCH BANKING (1961).

10 De novo branching refers to the building of branch offices by banks, as opposed to the buying of existing branches of other banking institutions.

11 Among the better known studies are: AlmadefF, Monopoly and Competrtion in Banking (1954); Flechsig, Banking Market Structure and Perforarance in Metropolitan Areas (1965); Horvitz, Concentration and Conspetition in New England Banking (1958); New York State Banking Departanent, Branch Banking, Bank Mergers and the Public Interest (1964); Alhadeff, $A$ Reconsideration of Restrictions on Bank Entry, 76 Q.J. Econ. 246 (1962); Carson \& Cootner, The Structure of Competition in Commercial Banking in the United States, in Private Financial Instirutions 55 (1963); Chandier, Monopolistic Elements in Commercial Banking, 46 J. PoL. EcoN. 1 (1938); Edwards, The Banking Competition Controversy, 3 National Banking Rev. 1 (1965); Flechsig, The Effect of Concentration on Bank Loan. Rates, 20 J. Finance 298 (1965); Horvitz \& Shull, The Impact of Branch Banking on Bank Performance, 2 NATIONAL BANKInG Rev. 143 (1964) ; Motter \& Carson, Bank Entry and the Public Interest: A Case Study, 1 Natronal BANKIng REv. 469 (1964); Schweiger \& McGee, Chicago Banking, 34 J. BusIness 203 (1961) ; Shull \& Horvitz, Branch Banking and the Structure of Competition, 1 National Banking Rev. 301 (1964).

12 Pa. Stat. Ann. tit. 7, \$\$101-2204 (Supp. 1965).

13 Pa. Stat. Ann. tit. 7, $\$ 1007$ (Supp. 1965).

14 PA. Stat. AnN. tit. 7, §1010 (Supp. 1965).

15 Pa. Stat. Ann. tit. 7, $\$ 905$ (Supp. 1965). 
tion of banks and branches ${ }^{16}$ and the assumption by one bank of the liabilities of another, including in the latter, bank mergers and consolidations. ${ }^{17}$ Minimum capital requirements for new banks are $\$ 50,000$ for places with population of less than $6,000, \$ 100,000$ for populations between 6,000 and 50,000 and $\$ 200,000$ for populations over $50,000 .^{18}$ The minimum capital requirements for new bank and trust companies or trust companies are somewhat higher. ${ }^{19}$ Additional capital and surplus are required for each de novo branch outside the city, borough or village in which the head office is located. The amounts required range from $\$ 25,000$ to $\$ 300,000$ of capital and $\$ 12,500$ to $\$ 150,000$ of surplus, depending again on the population of the place in which the branch is located and the type of institution established. ${ }^{20}$

De novo branching is permissible only in the same county in which the principal office is located or in a county contiguous to that county. ${ }^{21}$ When the proposed branch is located outside the city, incorporated town, borough or township in which the head office is located, the branching bank must give written notice to all other state banks in the county of the proposed branch. ${ }^{22}$ In those cases in which the proposed branch is in a county contiguous to the head office of the applicant bank, the Department of Banking may, "in its discretion," disapprove of the branch if any state bank with its head office in that county has indicated to the Department its good faith intention "to establish a branch in the same city, incorporated town, borough or township." 23

Legislative criteria for the establishment of de novo branches are that the Department find "that there is a need for banking services or facilities such as are contemplated by the establishment of the proposed branch and that the requirements . . . have been complied with." 24

16 Pa. Stat. Anv. tit. 7, §903 (Supp. 1965).

17 Pa. Stat. Ann. tit. 7, \$1604 (Supp. 1965).

18 Pa. Stat. Ann. tit. 7, \$1102 (Supp. 1965).

19 Ibid. For localities with populations of less than 6000 , the minimum capital for a bank and trust company or a trust company is $\$ 150,000$. A minimum of $\$ 200,000$ is required of such an institution located in a place with a population of between 6000 and 50,000 . In all other cases, a $\$ 300,000$ minimum is necessary. The population figures are determined by the last United States census of the place in which the institution's principal place of business is located.

20 Pa. Stat. Ann. tit. 7, §906(b) (Supp. 1965).

21 Pa. Stat. Ann. tit. 7, $\$ 904$ (b) (Supp. 1965).

22 Pa. Stat. ANn. tit. 7, $\$ 904$ (b) (iii) (Supp. 1965).

23 PA. Stat. ANN. tit. 7, $\$ 905$ (b) (Supp. 1965). Under the new code, hearings before the Department or before the Banking Board are left to the discretion of the Department. PA. STAT. ANN. tit. 7, \& 905(a) (Supp. 1965). Previously, the Banking Board had authority with respect to branches outside the place in which the head
office was located.

24 Pa. Stat. Ann. tit. 7, §905(c) (Supp. 1965). 
In addition to these, however, the Department must refer to the general instructions for its supervision of the banking system that it "exercise its discretionary powers" to provide for "the safe and sound conduct of the business of institutions subject to this act," "the conservation of their assets," "the maintenance of public confidence in them" and "the protection of the interests of their depositors, creditors and shareholders and of the interest of the public in the soundness and preservation of the banking system." 25

The Pennsylvania code permits mergers the effects of which do not violate the provisions with respect to de novo branching. Thus, existing branches of both of two merging banks may be operated provided they lie in the county or in a county contiguous to that of the head office of the resulting bank. ${ }^{26}$ The merger plans must be ratified by a majority of the directors and two-thirds of the shareholders of each institution. $^{27}$ In its examination, the Department of Banking is instructed to ascertain, among other things, whether "the plan and any modification thereof adquately protect the interests of depositors, other creditors and shareholders" 28 and whether "the merger or consolidation would be consistent with adequate and sound banking and in the public interest." With respect to the latter, the financial history and conditions of the merging banks, their prospects, the character of their management, the convenience and needs of the area to be served and the "potential effect of the merger . . . on competition" are to be considered. ${ }^{29}$ When the proposal is disapproved, the Department of Banking must state the reasons for its actions. ${ }^{30}$ In all instances the action of the Department of Banking is conclusive and not subject to review except upon broad certiorari. ${ }^{31}$ State action is held in abeyance until approval or disapproval has been received from the relevant federal agency acting under the federal Bank Merger Act. $^{32}$

Under the Pennsylvania Bank Holding Company Act of 1957,33 certain forms of intercorporate ownership and control of banking institutions are prohibited. ${ }^{34}$ Corporations or other forms of business associations are prohibited from holding $25 \%$ or more of the outstand-

25 Pa. Stat. Ann. tit. 7, § 103 (Supp. 1965).

26 Pa. Stat. ANN. tit. 7, \$904(a) (Supp. 1965).

27 Pa. Stat. ANN. tit. 7, 11603 (b) (ii) (Supp. 1965).

28 Pa. Stat. ANn. tit. 7, §1604(a) (ii) (Supp. 1965).

29 Pa. Stat. AnN. tit. 7, \$1604(a) (iv) (Supp. 1965).

30 Pa. Stat. ANN. tit. 7, \$1604(b) (Supp. 1965).

31 Ibid.

3280 Stat. 7 (1966).

33 PA. Stat. ANN. tit. 7, §\$ 851-55 (1965).

34 Pa. Stat. ANN. tit. 7, $\$ 853$ (1965). 
ing shares of each of two or more banks or from otherwise controlling the election of directors of two or more banks. ${ }^{3 \check{ }}$ It is unlawful for any company to become a holding company as so defined after the effective date of the act. ${ }^{36}$

National banks are chartered through the Office of the Comptroller of the Currency. ${ }^{37}$ The same office approves of de novo branches for national banks ${ }^{38}$ and, under the federal Bank Merger Act, of mergers in which the resulting bank will be nationally chartered. ${ }^{39}$ When the resulting bank is to be a state-chartered member of the Federal Reserve System, the Board of Governors must approve and, for insured, nonmember, state-chartered banks, the approval of the Federal Deposit Insurance Corporation is required. ${ }^{40}$ With respect to both de novo branching and branching by merger by national banks, the Comptroller of the Currency makes approvals within the constraints of state legislation pertaining to state-chartered banks. ${ }^{41}$

A summary of the statewide changes in the banking structure which have transpired in recent years can be gleaned from Table $1 .^{42}$ Over fourteen years, the total number of commercial banks has been reduced by 357 , with a total of 367 banks having been absorbed through mergers and one bank having ceased operation without being acquired by another. At the beginning of 1964, the number of banks in the state was roughly $68 \%$ of the number in existence at the beginning of 1950 .

Table 2 shows the changes in the number of branches operated by commercial banks over the same period. While the number of banks fell by 357, the number of branches increased by 867 . Stated alternatively, the number of commercial bank offices was 1,159 in 1950, and had risen to 1,669 by the beginning of 1964 .

The reduction in number of commercial banks since the early 1950 's is substantial by virtually any criterion. In fact, the number of bank mergers and absorptions in Pennsylvania from 1952 to 1964 exceeded by far that of any other state. It is also true, however, that at the beginning of the period Pennsylvania had a larger number of commercial banks than did any other state, including those states which

35 Pa. Stat. AnN. tit. 7, §852(b) (1965).

36 Pa. Stat. Ann. tit. 7, $\$ 853$ (1965).

37 Rev. Stat. $\$ 5169$ (1875), 12 U.S.C. $\$ 27$ (1964).

3848 Stat. 189 (1933), as amended, 12 U.S.C. $\$ 36(c)$ (1964).

3980 Stat. 7 (1966).

40 Ibid.

41 Ibid.; 76 Stat. 667 (1962), 12 U.S.C. \$36(b) (1964).

42 The tables are at $\mathrm{pp}$. $582-88$ infra. A more complete account can be found in P. Smith, Banks and Financral Institutions in Pennsylvania (1965). 
prohibit all forms of branching. ${ }^{43}$ Thus, despite the 347 mergers between 1952 and 1964, the number of banks remaining in 1964 was larger than that for any state permitting any form of branching and larger than that for any state except Illinois, Iowa, Minnesota, Missouri and Texas, in all of which branching is prohibited. ${ }^{44}$

The reduction in number of banks has not been evenly distributed within the state. In general, there have been large absolute and relative reductions in the number of banks with head offices in the metropolitan areas-the principal cities, their suburbs and immediate surrounding counties-compared with the rest of the state. For example, Table 3 shows the number of banks by county for 1956 and 1964 . The total reduction in number of banks between these dates was 198 . The reduction in twenty-two metropolitan area counties was $143(72 \%)$ and that in forty-five nonmetropolitan area counties was fifty-five (28\%) of this total. In other words, the metropolitan area counties had in 1964 only $69 \%$ of the number of banks in 1956 while the nonmetropolitan area counties had $85 \%$ of the 1956 figure. ${ }^{45}$ Only in the northwestern area nonmetropolitan counties has the reduction in number of banks been comparable to the metropolitan areas.

Of Pennsylvania's total of 621 banks at the beginning of 1964 , 222 operated branches and 399 were unit banks. By June 30, 1964, twelve additional unit banks had been absorbed, leaving 387 unit banks in the state. Of the latter, 217 were in counties outside of the state's twelve Standard Metropolitan Statistical Areas. In the same counties, 340 additional bank offices were operated by branch banks. A total of ninety-three branch banks had head offices in these counties. ${ }^{48}$ These banks operated 181 branches other than their head offices within the same counties in which head offices were located and sixty-six branches outside of the head office county. Branch banks with head offices outside of metropolitan areas thus operated an average of about 3.7 offices per bank. In contrast, the 129 branch banks with head offices within the metropolitan areas operated 617 branches other than their head office within the same counties in which head offices were located and 234 branches outside of the head office counties. These metropolitan

43 SMirth, op. cit. supra note 42, at 8; Banking Markets Untr, FEderal Reserve System, NuMrer of CoMmercial Banks aNd Branches BY States (1964); Changes in Banking Structure, 1953-1962, 49 FED. RESERVE BuLI. 1191, 1320 (1963).

44 Board of Governors, Federal Reserve System, Compillation of Federai, State, and Territorial Statutes Relating to Branch Banking (1961).

45 The number of bank offices in the cities and suburbs increased, of course, during this period. Because of the expansion in offices due to de novo branching, the number of banking alternatives available to customers in many instances became larger despite
the reduction in the number of head offices.

46 Sxrtr, op. cit. supra note 42 , at 8 . 
area banks operated an average of 7.6 offices per bank. A total of 170 unit banks remained in the metropolitan areas by the middle of $1964 .{ }^{47}$

In spite of the large number of banks per county and per metropolitan area, many of the smaller political units have very few or no banking offices. In 1962, 252 population centers outside of the metropolitan areas in the state-cities, boroughs, villages and townships-had only one commercial bank. Of these, 233 centers had populations of less than 5,000 persons. Five had populations of 15,000 or more. An additional sixty-nine centers had two banks, fourteen had three banks and eight had four, five or six banks. No center outside of metropolitan areas had as many as seven banks and no such center with a population of less than 5,000 persons had more than two banks. ${ }^{48}$ While these centers may be served to some extent by banks from outside of their geographic limits, it is nonetheless true that market concentration for most banking services in nonmetropolitan areas is relatively high. One or a very few banks occupy the bulk of the market.

In general, market concentration by metropolitan areas was not so great, though it is certainly true that geographic and product submarkets exist for some banking services within these areas. ${ }^{49}$ Table 4 shows deposit concentration for Pennsylvania's twelve Standard Metropolitan Statistical Areas. Aside from Altoona, Pittsburgh and Reading, the levels of concentration tend to be considerably lower than in the nonmetropolitan areas. In addition, the number of banks in all of the metropolitan areas is substantially larger. ${ }^{50}$

\section{Criteria for Assessing the Effictency of the Banking Structure}

The public concern with efficiency of markets is different from that of the businesses operating within those markets. For the latter, efficiency is largely a matter of whether the business succeeds in fulfilling the profit, power and growth aspirations of the owners and managers. Conventionally, measurement of business efficiency is likely to be expressed in such terms as profits, rates of return on capital, share of the market and similar indicators.

Efficiency from the public's point of view relates to the use of resources in the production of the goods and services which the public

47 Id. Appendix, at 83-87, 98-102.

48 This data was obtained from a special tabulation supplied by the Banking Markets Unit, Board of Governors of the Federal Reserve System.

49 Problems in and criteria for the definition of markets and submarkets are discussed in Brown Shoe Co. v. United States, 370 U.S. 294 (1962).

50 SmIтte, op. cit. supra note 42, at 28-30. 
demands. Here, measurement of efficiency involves principally the relations between resource inputs-human effort, capital and land useand the resulting output. Lower input per unit of output may be reflected in lower prices to consumers but, even where it is not, the minimizing of resource inputs for any one output activity maximizes the amount of resources available for the production of other goods and services. The first of these aspects of efficiency-that is, relations between costs and prices-affects the distribution of income, while the second affects the total real income available for distribution. Viewed over time, the public concern with efficient resource use extends to the adoption of cost-reducing innovations and the production of new and preferred goods and services.

With respect to commercial banking and banking market structure, the public interest can be viewed in terms of whether bank services are being produced at minimal costs, whether cost advantages are transmitted to the public in the form of price advantages and whether the firms in the markets tend to introduce process and product innovations.

\section{Size of Bank, Form of Bank and Costs}

Several empirical studies of relations between size of bank and costs have been completed in recent years. ${ }^{51}$ None of these studies is totally unassailable on either conceptual or methodological grounds, but the preponderance of evidence from the empirical studies, plus evidence from observed market phenomena, suggests the following factual situation:

1) In terms of total operating expenses per unit measure of size, or in terms of direct and relevant costs per unit of particular bank activities, average costs tend to decrease as the size of bank or level of activity increases up to certain minimum sizes. It seems quite certain that costs fall significantly as bank size increases up to between $\$ 5,000,000$ and $\$ 10,000,000$ in deposits and costs may continue to fall, though less significantly, beyond this. It is not known whether these economies of scale are due to technical factors associated with the production of banking services or to the possibly better quality of management and the greater pressures of competition facing the larger banks. ${ }^{52}$

51 Almadeff, Monopoly and Compettion in Banking (1954); Gramiey, A Study of Scale EConomres in Banking (1962); Benston, The Cost of Bank Operations (unpublished Ph.D. dissertation, University of Chicago 1964); Greenbaum, Banking Structure and Costs (unpublished Ph.D. dissertation, Johns Hopkins University 1964); Benston, Branch Banking and Economies of Scale, 20 J. FINANCE 312 (1965) ; Benston, Economies of Scale and Marginal Costs in Banking Operations, 2 NATIONAL BANKING REv. 507 (1965); Horvitz, Economies of Scale in Banking, in PRIVAte Financial. Institutions 1 (1963); Schweiger \& McGee, supra, nọte 11,
52 See authorities cited note 51 supra. 
2) There are positive costs associated with branching per se. $^{53}$ In general, if two banks are of equal deposit size and one is a unit bank and the other operates two or more offices, the latter will tend to have higher total costs than will the former.

3) The costs associated with branch office operations of a given size are, at least for small sizes and some locations, less than the costs of operating a unit bank of the same size at the same location. It is likely that the difference in costs between unit and branch operations at one location decreases rapidly as size increases.

The first two of these are consistent with the results of statistical studies. No study has attempted directly to verify the third and, because of the nature of the statement and limitations of data, it is doubtful that statistical tests are feasible. Two sorts of market phenomena do lend credence to the conclusion, however. First, the absorption of small banks into branching systems requires ipso facto that in each instance the acquiring bank be willing to pay for the acquired bank an amount equal to or more than the minimum expected value of continuing the operations of the acquired bank. Since the acquisition takes place only when the owners of both the acquired and acquiring bank believe themselves benefited there is a suggestion that more profits (or other measures of achievement of relevance to the banks) are available with the bank operating as a branch than as an independent unit. While other factors such as stock market imperfections may also be involved, the bank merger movement itself is consistent with, though not conclusive proof of, the contention that branches are sometimes less costly to operate than are unit banks.

Second, branch offices have been established de novo in locations and in sizes in which unit banks do not in fact tend to be established. The frequent occurrence of small branch offices in shopping centers, transportation terminals and office buildings, and the rarity, if not absence, of unit banks in similar locations and sizes, also argue that there are cost advantages for branch operations in some activities.

\section{Size of Bank, Market Structure and Prices}

Virtually all theories of market prices conclude that the smaller the number of firms in a market and the greater the market share of one or a few large firms, the greater is the likelihood of a high margin between cost and prices. ${ }^{54}$ This tendency is augmented, theoretical 
considerations suggest, when the customers of the firms are relatively large in number, uninformed about the market and unable to shop among alternative sources of supply.

Theory, then, raises questions as to whether the efficiency of larger banks and of branching might not fail to be passed on to bank customers because of these monopolistic influences. These questions would seem particularly pertinent for such bank services as small business loans, consumer financing and personal checking account services for which the demand conditions mentioned are most nearly met..$^{55}$

Some empirical studies have shown positive relationships between interest rates charged on business loans and concentration, ${ }^{56}$ while others of at least equal merit have raised serious questions concerning the validity of these conclusions. ${ }^{57}$ Within the cities covered by the studies, there are complicated interrelationships among size of city, size of bank, sizes and mixes of loans, interest rates and levels of concentration which have made definitive conclusions difficult. High concentration tends generally to occur in the smaller of these cities, in which the banks and average loan sizes are typically smaller than is the case for banks in the largest cities. After regional effects are removed, differences in loan sizes and mixes accounted for, and variation in rates among banks in given markets considered, the differences in loan rates sometimes no longer appear to be significantly or directly associated with bank concentration per se. It is clear, nonetheless, that on both theoretical and empirical grounds it would be preferable to find means for obtaining the economies of size and of branching without simultaneously increasing market concentration.

The problem of concentration is not, however, peculiar to large banks in large cities. In Pennsylvania, as in other states, ${ }^{68}$ high concentration tends to occur more often in the smallest of population centers in which one or a very few small banks occupy virtually the entire market. In these, both the smallness of the bank institutions and the limited alternatives of customers may, indeed, tend to produce

65 For a discussion of the differing market characteristics of various bank services, see id. at 356-57; Mitchell, Mergers Among Commercial Banks, in Perspectives on ANTITRust Policy 225 (Phillips ed. 1965).

56 Edwards, supra note 11; Schweiger \& McGee, supra note 11; Kaufman, Bank Market Structure and Performance: The Evidence From Iowa, 32 SouTHERN EcoNoxIC J. 429 (1966).

57 See studies by Flechsig, supra note 11, and Carson \& Horvitz, Concentration Ratios and Competition, 1 NATIONAI BANRING Rev. 105 (1963). It should be noted that the editorial process for scholarly publications tends to favor the publication of research which finds statistically "significant" associations among variables in comparison with other research dealing with the same variables but in which no "significant" association is found. See Tullock, Publication Decisions and Tests of Significance-A Comment, 54 J. AMERICAN Statistrcal A. 593 (1959).

58 Changes in Banking Structure, 1953-1962, 49 FED. RESERVE BuLL. 1191 (1963). 
higher prices, but this is hardly attributable to the behavior of banks which are large in absolute terms. Therefore, bank size must be related to market size in any application of theory.

There is no evidence to suggest that interest rates vary according to the legal form of the banking institution. In particular, branch banks have not been shown to have higher loan rates or lower rates on savings deposits than do unit banks. ${ }^{59}$ It is possible-but largely conjectural with the present state of knowledge-that holding company banks of the kind found in rural areas of states such as Iowa, Minnesota, Montana and North Dakota may have somewhat higher service charges and rates. Holding company banks, however, are typically small banks and it is difficult to isolate statistically the size effect from the holding company effect. Moreover, the banks owned by holding companies may simply be better managed in the sense that they rationally charge for certain services which small unit banks have traditionally supplied to customers without charge.

It is also true that banking markets are to a large extent regulated, partly by public authority ${ }^{60}$ and partly by the banks themselves. ${ }^{61}$ Both forms of regulation-whatever their other merits-tend to reduce the extent to which bank market structure affects market performance. Aggressive price competition in rates on loans, rates paid on deposits or service charges has historically been discouraged by private and public regulation alike. ${ }^{62}$ Similarly, such forms of nonprice competition as the granting of risky or exceptionally large loans are discouraged or prohibited. And again, truly collusive practices are more likely in small towns where banks are few and personal relations among bankers are closer than among banks in the larger cities.

Finally, it would appear that discrimination in the granting of loans and in interest rates charged would occur more among small town banks than among the larger ones. The close personal relations between bank customers and small, locally owned banks reflects but one side of the discrimination. For the established customer and friend of the banker, the discrimination is likely to be favor-

59 Flechigig, Banking Market Structure and Performance in Metropolitan AREAS 8 (1965).

60 United States v. Philadelphia Nat'1 Bank, 374 U.S. 321, 327-30 (1963).

61 On self-regulation, see Hodgman, Commercial Bank Loan and Investment Policy 120-35 (1963); Horbett, Banking Structure of United States, in BoARD of Governors, Federal Reserve System, Banking Studies 87, 106-07 (1941) ; Phillips, Competition, Confusion and Commercial Banking, 19 J. FrNaNCE 32 (1964); Robinson, Unit Banking Evalilated, in BankING AND Monetarx Studies 302 (Carson ed. 1963) ; Wojnilower \& Speagle, The Prime Rate, in Federal Reserve Bank of New YORK, ESSAYS IN MONEY AND CREDTT 47 (1964).

62 See authorities cited note 61 supra. Note, however, that recent policy with respect to Regulation $Q$, governing maximum interest on time deposits, has introduced a strong competitive element. 12 C.F.R. \$217.3 (Supp. 1966). 
able and the championing of the relationship, quite understandable. For the newcomer, for one who wishes credit to compete with an established customer, the discrimination is likely to have adverse effects. Here, the larger banks with impersonal rules with respect to loans may be far less discriminatory. None of the several studies of the pricing of bank services has found that larger banks and branch banks discriminate with respect to rates or the availability of credit in ways less favorable to the public than is true of smaller unit banks. ${ }^{\text {e3 }}$

\section{Product Mix, Innovations and Market Structure}

There are no authoritative studies relating to differences in product-mix and rates of innovating among banks. It is well known that banks do tend to specialize in certain services, sometimes to the point of outright exclusion of some, but more often in terms of the relative mix of services offered.

The New York State Department of Banking and other investigators have attempted to compare branch and unit bank operations. ${ }^{\text {G-1 }}$ It is found to be almost universally true that, in addition to physical improvements in facilities, the acquisitions of unit banks by branch banking systems lead to the introduction of previously unoffered services and to improvements in management techniques and conditions of employment. ${ }^{65}$ Some of this research has tested consumer attitudes with respect to the services offered by banks in unit banking, limited branch banking and statewide branch banking states but few reliable conclusions concerning consumer preferences can be made. ${ }^{68}$

Statistical studies of many industries demonstrate a rather general tendency for large firms to undertake a greater quantity of research and development work and to be responsible for a relatively large share of innovations. ${ }^{67}$ No such studies show that it is uni-

63 New York State Banking Department, Branch Banking, Bank Mergers AND tHe Public INTERest (1964).

64 Ibid.; Kreps, Character and Competittveness of Local Banking: A Sum.MAARY (1964); Wallace, Businessmen and Their Banks: Observations on Interbank Competition in Six Local Markets (unpublished, undated); Wallace, Banking Structure and Bank Performance: A Case Study of Three Small Market Areas (unpublished Ph.D. dissertation, University of Virginia 1965).

65 See Research into Banking Structure and Competition, 50 FED. Reserve BuLL. 1383, 1386-87, 1395-96 (1964).

${ }^{66}$ Wallace, Businessmen and Their Banks, supra note 64 , found in a survey of business that "North Carolina (state-wide branching) banks were performing more satisfactorily in the submarket for business loans." The comparison was with unit banks in West Virginia and limited branching in Virginia.

67 Representative of recent studies are Mansfield, Size of Firm, Market Structure and Innovation, 71 J. PoL. EcoN. 556 (1963); Scherer, Firm Size, Market Structure, Opportunity, and the Output of Patented Inventions, 55 AM. EcoN. REv. 1097 (1965). In none of the studies is the cause and effect relationship clear. In particular, it is 
versally true that greater size and concentration lead to more innovations; some suggest a reversal of the relationship after certain limits have been reached. ${ }^{68}$ There is no known research of this kind for banking. Casual observations, nonetheless, are sufficient to demonstrate that it is not the smallest of banks which account for the introduction of new bank services. They seem to come instead from an atmosphere of vigorous, nonprice competition among a fairly small number of relatively large banks whose goals appear to be growth and larger market shares. Similarly, changes in method of operations, including the introduction of automatic data processing and the use of computers, come first in the larger rather than the smaller banks.

In view of the paucity of analytic research in this area, it would perhaps be presumptuous to assert that larger banks possess innovative advantages over the smaller ones on the basis of observations alone. It clearly is not contrary to fact, however, to conclude conversely that there is simply no evidence that small banks are generally more progressive and render better services than do the large ones.

\section{Banking Market Policy for Pennsylvania}

The principal inefficiency in the existing banking market structure in Pennsylvania is demonstrated in Table 5. The average size of deposits for the 217 unit banks in nonmetropolitan counties was about $\$ 5,000,000$, the very conservative estimate of the minimum size consistent with efficient bank operations. As of June 30, 1964, 141 nonmetropolitan unit banks had deposits of less than $\$ 5,000,000$. There were seventy-six nonmetropolitan unit banks with deposits of less than $\$ 3,000,000$, and thirty-two with deposits of less than $\$ 2,000,000$. Only twenty unit banks outside of metropolitan areas had deposits in excess of $\$ 10,000,000$, the less conservative estimate of the minimum efficient scale. ${ }^{69}$

Of all the nonmetropolitan Pennsylvania counties, only Potter, Cameron, Sullivan, Fulton, Union and Montour had no branch banks in addition to the unit banks shown. Because county data on deposit size do not reveal the size of the branch systems with offices in more than one county, estimates by county of the size of the nonmetropolitan branch banks cannot be made. Many, however, must themselves be

not known whether firms which successfully innovate grow more rapidly than do others and, hence, tend to be large or whether large size is a necessary condition for successful innovation in some industries. It is clear that size alone is not a sufficient condition for relatively high rates of innovation.

68 Williamson, Innovation and Market Structure, 73 J. PoL. Econ. 67 (1965).

69 This data is compiled from Rand McNatly, International Bankers DIRECTORY (Rand MeNally ed. 1964). 
relatively small banks. It is in these areas of the state that the "onebank towns" are found. Cameron County has but one commercial bank office; Forest, Sullivan, Fulton and Montur counties have two bank offices. All the other counties have five or more offices, but many communities in them have none or only one office.

It is apparent, of course, that one of the reasons for towns with no banks or with only one bank is that the market for banking services is simply too small to support a larger number of even the most efficiently operated bank organizations. Where this is true efficiency requirements would dictate that no additional facilities be located in these centers. It seems also true, however, that in the counties and towns with one or more unit banks of very small size, efficiency requirements would dictate that they be operated as branches of a larger system in many instances. That this has not transpired under the present code is testimony to the fact that, with that code, banking competition has not been active enough to force banks of less than optimum efficiency to alter their organization, improve their management or to fail. ${ }^{70}$

It should be noted that the same inability of competition to force the exit or combination of small unit banks has prevailed, though to a lesser extent, in the metropolitan areas. Table 6 shows the number of unit banks and the average deposit size of these banks for metropolitan areas. While the average size of these banks is more than half again that of banks in nonmetropolitan counties, some smaller than optimum banks-perhaps nearly one hundred-remain in the metropolitan areas even after the numerous mergers of the past fifteen years. The Johnstown and Reading areas seem particularly to have missed the type of bank combinations which would have eliminated small unit banks. And Reading, it may be recalled, has a high level of market concentration.

The efficiency criterion, while of primary economic importance, is not sufficient for policy purposes. To the extent that it is possible to accomplish, the goal should be an efficient bank structure which at the same time preserves (or makes possible) competition, alternative sources of bank services for customers and the pricing of bank services in a nonmonopolistic way. The present Pennsylvania code, while permissive of efficiency gains through intra-county and contiguous county bank mergers, fails to permit these gains in the manner most consistent with the preservation of competition.

The essential weakness of Pennsylvania's geographically limited branching law is that only those mergers which reduce the number of banks within given market areas are permitted. Mergers between

70 See Phillips, supra note 61 . 
banks from different areas which would not reduce the number of banking alternatives in either area are largely prohibited. ${ }^{71}$ Thus, for example, the code allows mergers of banks within, say, the Philadelphia or Pittsburgh or Scranton areas and it permits mergers of banks within, say, McKean or Forest or Sullivan counties or the contiguous counties. It prohibits a Philadelphia, Pittsburgh or Scranton bank from acquiring banks in McKean, Forest or Sullivan counties and prohibits a Philadelphia bank from acquiring a Scranton bank, a Scranton bank from acquiring a Pittsburgh bank, etc.

Paradoxically, it is these prohibited forms of branching which may be most consistent with maintaining (and increasing) competition while at the same time permitting the achievement of economies of scale and of branching. The possibility that a Philadelphia bank might enter the Pittsburgh market via the acquisition of one of the many small unit banks in the latter is a far more effective constraint on the market power of the few large Pittsburgh banks than is the possible consolidation of the small Pittsburgh banks. The latter would increase concentration and reduce alternatives available to bank customers in Pittsburgh; the former would not directly affect concentration or the number of alternatives in the Pittsburgh market and would add an element of inter-regional competition among Pennsylvania's large banks.

In the same way, the permission of acquisitions of small country banks by metropolitan area branching systems is conducive to the inhibition of local monopolistic influences stemming from local unit banks or local branching system banks. It is precisely this sort of acquisition which is most likely to bring to smaller communities the wider services and, sometimes, the lower cost and lower priced services of city banks which have, in general, a more competitive market environment in the areas in which their head offices are located.

These arguments apply-though with somewhat less force-to the so-called "trade area" or "regional branch banking" and to the "Virginia Plan" types of branching limitations." ${ }^{72}$ In the former, a state is divided into a few largely arbitrarily drawn regions and mergers are permitted within but not among them. In the latter, statewide branching by merger is permitted, but de novo branching is restricted to the main office city or county.

Applied to Pennsylvania, "trade area" branching would largely prohibit the potential competition which may arise from the interface

71 Pa. Stat. ANn. tit. 7, §904(b) (Supp. 1965).

72 The regional branching scheme is well illustrated by the New York structure. See N.Y. Banking Law $\$ \S 3,105,600,601$; Comment, 115 U. PA. L. Rev. 218 (1966). The "Virginia Plan" is exemplified by the banking statutes of that state. VA. CoDE ANN. \& 6.1-.39 (1966). 
of branches of larger banks from different metropolitan areas. A Philadelphia bank, for example, could in no circumstances compete through branching with a Pittsburgh bank in any section of the state. Depending on the number and configuration of the areas, the possibly beneficial effects of inter-regional competition would thus be precluded and protection would be afforded to large banks from competition with other large banks.

The "Virginia Plan" for branching does not prevent this kind of competition, but rather tends to shelter small banks by preventing office proliferation by the branching systems. Here the weakness is that the economies of small-scale branch offices and the convenience to the public of more branch locations are denied. With the existing large number of small unit banks, the encouragement of rural area branching rather than its restriction would appear to be the more appropriate policy for Pennsylvania.

This is not to say that branching should be entirely unrestricted. The above examples have purposely been chosen to demonstrate "procompetitive" effects of wider branching. It is quite possible-indeed, likely-that completely unrestrained bank mergers could lead to the development of a concentrated statewide banking structure which would be unjustified by scale economies and inconsistent with competition. There is, for example, little reason to suspect that the joining of the largest bank in one metropolitan area with that of another area would create scale economies. There is ample reason to suspect that a number of such mergers would reduce inter-regional competition.

It is similarly desirable to avoid unwarranted metropolitan bank concentration. It may be contended that further mergers among Philadelphia or Pittsburgh banks are necessary in order that Pennsylvania have banks as large as those in other major financial centers. Some large borrowers located within the state have recourse to larger banks in New York and other cities. Because of this, the possibility of mergers among banks of a given metropolitan area has obvious appeal from the point of view of these banks, since business is being lost to other banks.

The social merits of permitting bank mergers for this purpose are not clear. The performance of the national market for large commercial loans is unlikely to be influenced perceptibly by the entrance of one or two Pennsylvania banks. It is a market generally regarded as adequately competitive and with growing sources of funds outside of commercial banking. In addition, there is little evidence that large borrowers are in fact inconvenienced by having to rely on banks in other cities. "Shopping" for large loans is not uncommon and the 
incremental costs to borrowers of contacting banks in other cities are probably negligible. It is undemonstrated and likely undemonstrable that the industrial growth of the state is in any appreciable way adversely affected by the absence of multi-billion dollar commercial banks. Finally, larger banks which arose from mergers among banks which, prior to merger, were not in a competitive relationship would be as efficacious in competing in the market for large loans as would those which result in a lessening of competition in local markets.

\section{Policy Conclusions}

\section{Branching and Mergers}

These considerations suggest that the provisions in the Pennsylvania code with respect to branching should be amended in the following ways:

1) The provisions preventing de novo branching and branching by merger outside the county and contiguous counties of head offices ${ }^{73}$ should be eliminated. Changes in other criteria to be applied in the approval of mergers are discussed below. 2) While section $1604^{74}$ now requires that, among other things, the Department ascertain the "potential effect of the merger or consolidation on competition," the code should be further amended to give primacy to the competitive test. More specifically:

(a) The code should indicate that sections 103 (a) and 103(b),$^{75}$ which establish that the Department should act to provide for the "safe and sound conduct" of banks, the "conservation of their assets," the "protection of the interests of their .. . shareholders" and "the interest of the public in the soundness and preservation of the banking system," should not be interpreted in a manner which negates the interests of the public in an efficient and competitive banking system. It is certain that increased competition would indeed pose some threat to the safety of individual institutions and to their shareholders. It is just this threat which is required if the market is to induce greater efficiency. Literally applied, these standards would prevent those mergers which are most directly in the public interest.

(b) The "need" criterion of section 905 (c) ${ }^{76}$ with respect to de novo branches and the "convenience and 
needs" criterion of section $1604^{77}$ for mergers and consolidations should be deleted. In some circumstances, "convenience and needs" might be used to prevent mergers or branches which promise beneficial public effects but which are likely adversely to affect existing banks not party to the plans. In other circumstances, "convenience and needs" arguments might be used to permit mergers or branches the effects of which are likely to be strongly anticompetitive. ${ }^{78}$ In any circumstances, the "convenience and needs" test is difficult to comprehend and it approaches the fictitious when applied.

(c) The preference given in section 905 (b) ${ }^{79}$ to statechartered banks for the establishment of branches in their own areas should be eliminated. This, together with the contiguous county branching rule, ${ }^{80}$ is indicative of the protection against competition which the current code affords.

(d) With these changes, section 1604 (a) (iv) ${ }^{81}$ could be reduced to an instruction that the Department should ascertain whether "the merger or consolidation would be consistent with the public interest on the basis of . . . the potential effect of the merger or consolidation on competition." The assessment of potential competitive effects necessarily involves findings with respect to the financial history of the merging banks, of their prospects and of their management. Further-and most important--such language makes the competitive test clearly paramount in the Department's considerations. With any effort at conscientious application, the test would make it more difficult for banks to expand within narrow economic areas than is currently the case. Similarly, conscientious application would make it difficult to justify the merging together of any of the state's largest banks. The test would not, on the other hand, prevent the merging together of small banks which had not had competitive relations with one another nor, in many cases, the entry of large banks into new markets through the acquisition of small banks in those markets.

The changes which are suggested with respect to mergers would to some extent cause an overlap between state and federal policies. Federal antitrust policy, as enunciated in United States $v$. Philadelphia

77 Pa. Stat. ANN. tit. 7, \$1604 (Supp. 1965).

78 It should be noted that the Bank Merger Act of 1966 now incorporates a "convenience and nceds" test. 80 Stat. 7.

79 Pa. Stat. Ans. tit. 7, § 905 (b) (Supp. 1965).

80 Pa. Stat. ANn. tit. 7, \$904 (Supp. 1965).

81 Pa. Stat. Ann. tit. 7, \$1604(a) (iv) (Supp. 1965). 
National Bank ${ }^{82}$ and United States v. First National Bank \& Trust Co., ${ }^{83}$ is clearly applicable to mergers between major banks in any metropolitan area. ${ }^{84}$ The same policy and that which has arisen under the 1960 Bank Merger Act ${ }^{85}$ would very probably also prevent the merger of major banks from separate metropolitan areas in the same state where the resulting bank would be large relative to other banks in the same state. Thus for such mergers, the proposed competitive criterion may be employed by the federal antitrust or banking agencies whether or not it is incorporated in state policies.

The federal agencies are less apt to prevent mergers when the banks and the relevant market areas involved in a merger are smaller. For this reason, state policy becomes the crucial determinant for bank mergers for a major segment of the state's banking industry. Furthermore, while metropolitan banks are in absolute terms the largest, it is also true that they typically operate in markets which are more competitive than the markets outside of metropolitan areas. State policy, that is, is likely to remain the main vehicle for establishing and maintaining competition in the very areas in which the competitive problem is most acute. It would be a mistake of major proportions to believe that federal antitrust policy preempts the entire field.

\section{Holding Companies}

With these changes in branching provisions, it is doubtful that any holding company could achieve the same economies of operation as would a branch system. Holding companies appear almost entirely in states in which branching is prohibited or where the limitations on branching provide special opportunities for holding company operations. In Virginia, for example, the prohibition of additional branching within a county in which a bank has been acquired has favored the growth of holding companies along with the development of statewide branching by merger.

That holding companies are unable to duplicate the economies of branching operations is in part inherent in their organization. The individual corporations remain and much of the pooling and specialization of tasks possible with a branch system are impossible with the holding company. ${ }^{86}$ In particular, each holding company bank is sub-

82374 U.S. 321 (1963) ( $\$ 7$ Clayton Act violation).

83376 U.S. 665 (1964) ( $\$ 1$ Sherman Act violation).

84 This policy may, of course, be somewhat modified by the 1966 bank merger legislation. 80 Stat. 7.

8574 Stat. 129.

86 For a generally concurring view, see Fischer, Bank Holding CompanIes (1961). For a more favorable view of holding companies, see NADLER \& BogEN, THE Bank Holding Company (1959). The latter reference does not, however, argue that holding companies are as efficient as branch banking. 
ject to the requirements and regulations relative to unit banks. Further, those holding companies qualifying under the federal Bank Holding Company Act of $1956^{87}$ are forbidden to make "upstream loans" within their system. "Downstream loans" and loan participations are regulated by the Board of Governors. ${ }^{88}$ Correspondent relations are frequently more convenient when loan participations are necessary.

It does not follow that the Pennsylvania Bank Holding Company Act should be repealed. It is quite possible that, where mergers among banks might be prohibited because of anticompetitive effects, holding companies might appear as an alternative. Some banks might also be willing to be a part of a holding company while unwilling to merge because of the retention of local identity and local officers in the holding company organization. It appears, then, that the present law prohibiting this device should be retained.

It should be recognized, nonetheless, that neither the federal nor the state law necessarily accomplishes all of its avowed purposes. The $25 \%$ ownership rule does not prevent control based on a smaller percentage of ownership. Informal "chain bank" ownership by noncorporate entities may accomplish the same end as do holding companies. Further, since the ownership or control of two or more banks is necessary to violate the law, those fraudulent transactions which can be arranged through the ownership or control of a single bank are not prevented. ${ }^{89}$

\section{Chartering}

The entry of new banks into markets through chartering creates the same restraint on monopolistic influences as does entry through inter-market branching. In the case of chartering, it can be argued that the competitive effect is even greater since an additional alternative for bank customers is created. For the same reasons that inter-market branching was argued to be desirable, it can be and has been contended that entry by chartering should be facilitated. ${ }^{90}$

While mergers tend to increase the average size of banks, to reduce the number of banks and-where the minimum efficient scale does not exist-to achieve scale economies, the possible proliferation of small banks through unrestricted chartering moves in exactly the opposite direction if bank disappearances are not simulanteously permitted. Accordingly, it is concluded that if the changes suggested with

8770 Stat. 133 (1956), as amended, 12 U.S.C. $\$ \$ 1841-48$ (1964).

8870 Stat. 134 (1956), 12 U.S.C. $\$ 1842$ (1964).

so See Hall, Bank Holding Company Regulation, 31 SoutherN Economic J. 342 (1965).

30 Alhadeff, A Reconsideration of Restrictions on Bank Entry, 76 Q.J. EcoN, 246 (1962). 
respect to mergers and branching were adopted, the criteria for charters should also be amended to facilitate newly organized banking institutions.

The most reasonable amendment would allow far from completely unrestrained entry. The existing minimum capital requirements are not so large that they erect a formidable barrier. Indeed, if scale economies do extend to banks of $\$ 5,000,000$ or $\$ 10,000,000$ in deposits, the present capital requirements permit the establishment of banks of substantially less than optimum scale. ${ }^{91}$ The existence of the requirements does, however, prevent banks from being established on the basis of the mere caprice of an organizer and for this reason alone their retention seems desirable.

It is also reasonable that the Department of Banking should inquire into the intentions of bank organizers for the purpose of preventing fraud. Both the depositors and the subscribing shareholders of a new bank require this "blue sky law" type of protection. Similarly, the chartering agency should investigate the prospects of a new bank growing to such size as will be efficient within the proposed market.92

If these are the only considerations in chartering, entry would be considerably easier than under the current "convenience and needs of the public" standard.93 The latter, as typically interpreted by chartering agencies, is an extraordinarily ambiguous concept which in application reduces to preferences for and protection of the existing banks in a market. It is in this respect that chartering should be made less difficult. If a proposed new bank meets the capital requirements, if its organizers have the legitimate purpose of attempting profitably to operate a commercial bank and if there are reasonable prospects of success, charters should be granted even if success for the new bank implies loss of business and the likely disappearance of banks currently occupying the market. The relaxed merger standards would afford a means for the less successful banks-whether new or old ones-to disappear without a public crisis and with losses occurring only to the owners of inefficient enterprises. In these circumstances, the easier entry provisions would be effective in forestalling both monopolistic influences and in preventing gross operating inefficiencies.

Entry, it should be emphasized, can prevent neither monopoly nor inefficiency if every bank, once established, has its existence preserved by regulation. It is essential, if both ends are to be achieved, that any changes making chartering less restrictive be accompanied by the

01 See Pa. Stat. Ann. tit. 7, §1102 (Supp. 1965); authorities cited note 51 supra. 92 Pa. Stat. Ann. tit. 7, $\S 1007$ (Supp. 1965) so provides.

93 PA. Stat. Ann. tit. 7, $\$ 1007$ (a) (ii) (Supp. 1965). 
possibility of failing banks' being acquired by banks outside of their own market area.

\section{A Postscript}

These conclusions will surely appear radical to many bankers. On the one hand, the existence of a large number of small banks-mostly in rural areas but some in cities as well-would be less secure than it currently is. That is a necessary cost of attaining greater efficiency. On the other hand, the possible emergence of a few large banks dominating city banking markets and possibly the entire state is to be avoided. It was indicated in the introduction that the conclusions of this article would be on the impact of the banking structure on the "commonweal." This, it is felt, would be better served with the recommended changes. It is quite apparent that, to gain efficiencies, the number of banks in the state would continue to be reduced were the recommendations followed. It is equally apparent, however, that the past trend toward concentration in the distinguishable markets for services such as small business loans, consumer loans and small business and personal deposit services would be less strong than under the present code. 


\section{APPENDIX}

TABLE $1^{94}$

Changes in the Number of Commercial Banks in Pennsylvania, 1950-1964

Number of Banks New Banks Banks Ceasing Operation

\begin{tabular}{lccccc} 
Year & $\begin{array}{c}\text { at Beginning of } \\
\text { Period }\end{array}$ & $\begin{array}{c}\text { Beginning } \\
\text { Operation }\end{array}$ & $\begin{array}{c}\text { Mergersand } \\
\text { Consolidations }\end{array}$ & Other & $\begin{array}{c}\text { Net } \\
\text { Change }\end{array}$ \\
\hline 1950 & 978 & 1 & 8 & - & -7 \\
1951 & 971 & 1 & 12 & - & -11 \\
1952 & 960 & 1 & 21 & - & -20 \\
1953 & 940 & - & 36 & - & -36 \\
1954 & 904 & - & 45 & - & -45 \\
1955 & 859 & - & 41 & - & -41 \\
1956 & 818 & 2 & 28 & - & -26 \\
1957 & 792 & - & 21 & - & -21 \\
1958 & 771 & 1 & 29 & - & -28 \\
1959 & 743 & - & 21 & - & -21 \\
1960 & 722 & - & 19 & - & -19 \\
1961 & 703 & - & 26 & 1 & -27 \\
1962 & 676 & 1 & 39 & - & -38 \\
1963 & 638 & 4 & 21 & - & -17 \\
1964 & 621 & & & & -357 \\
\hline $1950-1964$ & 978 & 11 & 367 & 1 &
\end{tabular}

TABLE $2^{95}$

Changes in the Number of Branches Operated by Comarercial Banks in Pennsylvanta, 1950-1964

\begin{tabular}{lcccc} 
Year & $\begin{array}{c}\text { Number of Branches } \\
\text { at Beginning of } \\
\text { Period }\end{array}$ & $\begin{array}{c}\text { Branches Opened, } \\
\text { Converted or } \\
\text { Replaced }\end{array}$ & $\begin{array}{c}\text { Branches } \\
\text { Closed }\end{array}$ & $\begin{array}{c}\text { Net } \\
\text { Change }\end{array}$ \\
\hline 1950 & 181 & 12 & - & +12 \\
1951 & 193 & 27 & - & +27 \\
1952 & 220 & 39 & 3 & +36 \\
1953 & 256 & 60 & 2 & +58 \\
1954 & 314 & 86 & 4 & +82 \\
1955 & 396 & 83 & 8 & +75 \\
1956 & 471 & 72 & 5 & +67 \\
1957 & 538 & 62 & 4 & +58 \\
1958 & 596 & 77 & 2 & +75 \\
1959 & 671 & 71 & 2 & +69 \\
1960 & 740 & 58 & 5 & +53 \\
1961 & 793 & 82 & 1 & +81 \\
1962 & 874 & 76 & 3 & +73 \\
1963 & 947 & 104 & 3 & +101 \\
1964 & 1,048 & & & +867 \\
\hline $1950-1964$ & 181 & 907 & 42 & \\
\hline
\end{tabular}

94 Source: Unpublished compilations by Banking Markets Unit, Board of Governors of the Federal Reserve System [hereinafter cited as Banking Markets Unit]. 95 Ibid. 
TABLE $3^{90}$

Number of Banks in Metropolitan Area Counties and in Nonmetropolitan Area Counties, 1956 and 1964

\begin{tabular}{|c|c|c|}
\hline \multirow{2}{*}{ Area and County } & \multicolumn{2}{|c|}{ Number of Banks 97} \\
\hline & August 31, 1956 & June 30,1964 \\
\hline \multicolumn{3}{|l|}{ Metropolitan Areas: } \\
\hline Allentozen, Bethlehem, Easton & 35 & 26 \\
\hline Lehigh & 15 & 9 \\
\hline Northampton & 20 & 17 \\
\hline Altoona & 12 & 5 \\
\hline Blair & 12 & 5 \\
\hline Erie & 14 & 12 \\
\hline Erie & 14 & 12 \\
\hline Harrisburg & 42 & 24 \\
\hline Cumberland & 15 & 10 \\
\hline Dauphin & 27 & 14 \\
\hline Johnstown & 38 & 27 \\
\hline Cambria & 22 & 15 \\
\hline Somerset & 16 & 12 \\
\hline Lancaster & 34 & 25 \\
\hline Lancaster & 34 & 25 \\
\hline Philadelphia & 84 & 49 \\
\hline Bucks & 14 & 8 \\
\hline Chester & 21 & 13 \\
\hline Delaware & 2 & 2 \\
\hline Montgomery & 23 & 12 \\
\hline Philadelphia & 24 & 14 \\
\hline Pittsburgh & 80 & 50 \\
\hline Allegheny & 43 & 23 \\
\hline Beaver & 12 & 10 \\
\hline Washington & 4 & 3 \\
\hline Westmoreland & 21 & 14 \\
\hline Reading & 21 & 17 \\
\hline Berks & 21 & 17 \\
\hline Scranton & 21 & 20 \\
\hline Lackawanna & 21 & 20 \\
\hline Wilkes-Barre, Hazleton & 35 & 27 \\
\hline Luzerne & 35 & 27 \\
\hline York & 26 & 17 \\
\hline York & 26 & 17 \\
\hline \multicolumn{3}{|l|}{ Nonmetropolitan Areas: } \\
\hline Northwestern & 64 & 42 \\
\hline Armstrong & 11 & 11 \\
\hline Butler & 4 & 3 \\
\hline Crawford & 10 & 7 \\
\hline Lawrence & 7 & 4 \\
\hline McKean & 9 & 5 \\
\hline Mercer & 13 & 7 \\
\hline Venango & 7 & 4 \\
\hline Warren & 3 & 1 \\
\hline
\end{tabular}

96 Source: Jolnt State Governiment Comm'n, Brance Banking (1957); P. Saith, Banks and Otakr Financial Institutions in Pennsylvania (1965). 
TABLE 3 (Continued)

Number of Banks in Metropolttan Area Counties and in Nonmetropolitan Area Counties, 1956 and 1964

Area and County $\quad \frac{2}{\text { Number of Banks } 97}$

Nonmetropolitan Areas:

Northeastern

Bradford

48

46

Potter

Susquehanna

Tioga

Wayne

Wyoming

North Central

Cameron

Clinton

Elk

Forrest

Lycoming

Sullivan

Sonthrestern

Clarion

Clearfield

Fayette

Greene

Indiana

Jefferson

Central

Bedford

Centre

Fulton

Huntingdon

Juniata

Mifflin

Perry

Snyder

Union

Eastern

Carbon

Columbia

Monroe

Montour

Northumberland

Pike

Schuyikill

Southeastern

Adams

Franklin

Lebanon

14

6

5

9

8

6

33

1

7

6

1

16

2

35

3

7

6

3

10

6

64

9

11

2

11

8

5

9

4

5

80

11

10

4

3

20

2

30

41

13

16

12
13

6

5

9

8

5

29

1

6

5

1

14

34

2

2

7

5

3

11

6

55

8

10

2

9

6

5

7

3

5

72

11

10

3

2

18

2

26

32

11

11

10

Total-Metropolitan Areas

442

365

299

310

807

609

97 The number of unit banks and branch banks with head offices in the respective areas and counties. 
TABLE 498

Percent of Total Deposits Held by Largest Banks With Head Offrces in Metropolitan Areas of Pennsylvanta, June 30, 1962

\section{Percent of Total Deposits}

Metropolitan Area Largest Bank Largest 2 Banks

Allentown-Bethlehem-Easto
Altoona
Erie
Harrisburg
Johnstown
Lancaster
Philadelphia 99
Pittsburgh
Reading
Scranton
Wilkes-Barre-Hazleton
York

17.8

42.1

32.3

26.8

24.3

15.3

19.1

49.9

40.5

36.2

18.6

22.5
28.9

72.4

59.3

49.8

37.4

29.0

36.0

72.5

61.6

50.2

33.9

44.6 
TABLE 5100

Number and Average Size of Unit Banks in Counties Outside of Metropolitan Areas in Pennsylvania, Juñe 30, 1964

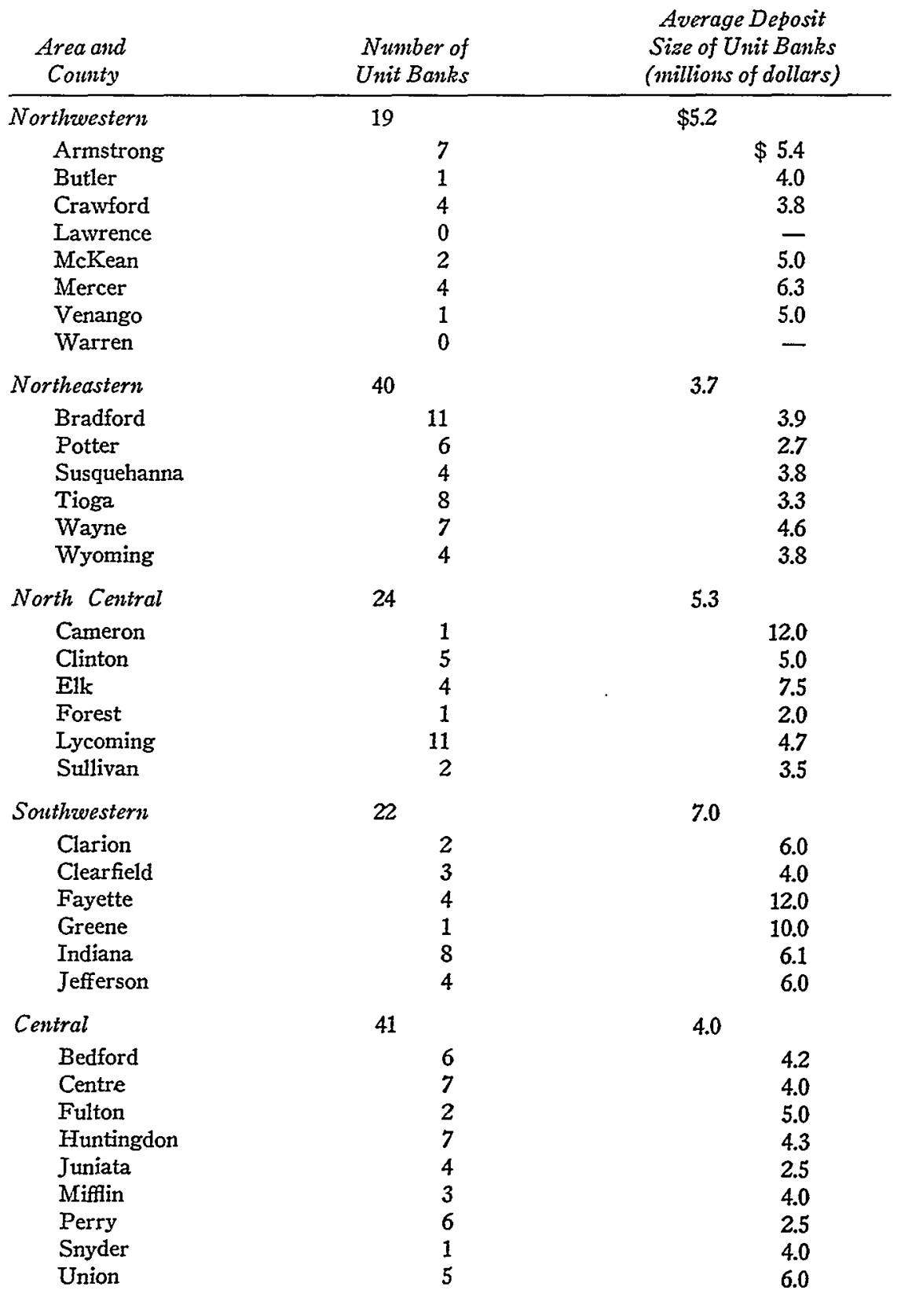

100 Source: Banking Markets Unit. 
TABLE 5 (Continued)

Number and Average Size of Unit Bants in Counties Outside of Metropolitan Areas in Pennsylvania, June 30, 1964

Average Deposit

Area and

Number of Unit Banks Size of Unit Banks

County

50 (nillions of dollars)

Eastern

Carbon

Columbia

Monroe

Montour

Northumberland

Pike

Schuylkill

5.3

8

4

4.3

1

6.0

2

11.0

13

8.5

1

4.6

21

6.0

5.5

Southeastern

21

5.5

Adams

Franklin

Lebanon

9
6
6

3.4

5.0

9.2

All Nonmetropolitan Counties 217

5.0 
TABLE 6101

Number and Average Size of Unit Banks in Metropolitan Areas in Pennsylvania, June 30, 1964

\begin{tabular}{lcc}
\multicolumn{1}{c}{ Metropolitan Area } & $\begin{array}{c}\text { Number of } \\
\text { Unit Banks }\end{array}$ & $\begin{array}{c}\text { Average Deposit } \\
\text { Size of Unit Banks } \\
\text { (millions of dollars) }\end{array}$ \\
\hline Allentown-Bethlehem-Easton & 17 & $\$ 8.4$ \\
Altoona & 0 & - \\
Erie & 2 & 7.0 \\
Harrisburg & 18 & 6.7 \\
Johnstown & 16 & 3.8 \\
Lancaster & 15 & 6.3 \\
Philadelphia & 18 & 8.8 \\
Pittsburgh & 32 & 8.3 \\
Reading & 10 & 5.9 \\
Scranton & 17 & 10.0 \\
Wilkes-Barre-Hazleton & 16 & 8.3 \\
York & 9 & 7.4 \\
All Metropolitan Area Unit Banks & 170 & 7.6
\end{tabular}

